\title{
AKTUALISASI PANCASILA SEBAGAI LANDASAN POLITIK HUKUM INDONESIA
}

\author{
Derita Prapti Rahayu \\ Fakultas Hukum Universitas Bangka Belitung; Mahasiswa Program Doktor \\ Ilmu Hukum Fakultas Hukum Universitas Diponegoro \\ Email: deritapraptir@yahoo.com
}

\begin{abstract}
Pancasila is a major cornerstone in the making of law (law and Legislation) with a new or replacement of laws (political law), so that the values of the Deity, Humanity and Society (nationalistic; democratic; social justice) must be actualized into the substance of the law, the legal structure and legal culture to be built, is expected to strengthen national integration, democratization of law, achieve prosperity and social justice by putting Pancasila, ranging from values, goals until the actualization of the various fields of existing law, whether criminal, civil, administrative and the other, as well as the internalization of the structures of law and legal culture of Pancasila.
\end{abstract}

Keywords : Actualization, Pancasila, Politics of Law

\begin{abstract}
Abstrak
Pancasila merupakan landasan utama dalam pembuatan hukum (Peraturan Perundang-Undangang) baru maupun dengan penggantian hukum lama (politik hukum), sehingga nilai-nilai Ketuhanan, Kemanusiaan dan Kemasyarakatan (nasionalistik; demokratik; berkeadilan sosial) harus teraktualisasi kedalam substansi hukum, struktur hukum maupun kultur hukum yang akan dibangun, diharapkan dapat menguatkan integrasi bangsa, demokratisasi hukum, tercapainya kesejahteraan dan keadilan sosial dengan menempatkan Pancasila, mulai dari nilai, tujuan sampai dengan aktualisasi kepada berbagai bidang hukum yang ada, baik hukum pidana, perdata, tata usaha negara dan lain-lain, serta internalisasi pada struktur hukum dan budaya hukum Pancasila.
\end{abstract}

Kata Kunci : aktualisasi, Pancasila, Politik Hukum

\section{A. Pendahuluan}

Setiap Negara pasti mempunyai politik hukumnya sendiri-sendiri baik Negara maju ataupun bukan, tidak ada politik hukum Negara satu berlaku untuk Negara lain, tapi tidak menutup kemungkinan Negara satu dapat 
mempengaruhi Negara lain untuk membentuk hukum menurut negaranya, meratifikasi, menjadikan konvensi Internasional menjadi Undang-Undang di negaranya. Begitupula Indonesia mempunyai politik hukumnya sendiri (Mumpuni Martojo, 2007: 1). Politik hukum baru yang berisi pembaruan hukum menjadi keharusan bagi Indonesia sebagai negara merdeka semenjak diproklamirkan demi mewujudkan cita-cita dan tujuan negara Indonesia.

Proklamasi kemerdekaan Indonesia tanggal 17 Agustus 1945 membawa perubahan besar dalam semua aspek kehidupan bangsa Indonesia, termasuk penyelenggaraan hukumnya. Dalam menata kerangka dan struktur dasar organisasi negara di sahkanlah Undang-Undang Dasar 1945 (sekarang UndangUndang Dasar Negara Republik Indonesia 1945) yang di dalam batang tubuh Pasal 1 (3) dinyatakan Negara Indonesia adalah negara hukum. Oleh karena itu menuntut pembaruan atau penggantian hukum dari hukum penjajah menjadi hukum nasional dimana perubahan itu perlu dan menjadi bagian penting dari politik hukum nasional (Esmi Warassih, 2005: 43), sehingga dapat mewujudkan cita hukum yang diinginkan bangsa Indonesia.

Pemilihan judul di atas dilatarbelakangi oleh pengamatan penulis sebagai bangsa Indonesia yang merasakan pasang surutnya Pancasila sebagai satusatunya asas dalam kehidupan berbangsa dan bernegara, baik dalam pembahasan maupun dalam tataran penerapannya bahkan politik hukumnya. Politik hukum di negara kita cenderung tidak lagi mewakili falsafah tertinggi kita yaitu Pancasila. Pancasila sebagai landasan politik hukum jika di masukkan dalam determinasi politik dan hukum, maka dalam hal ini akan difokuskan pada hukum deterninan atas politik karena setiap agenda politik harus tunduk pada hukum, hukum dalam hal ini diartikan sebagai UndangUndang atau Peraturan tertulis yang dibuat dan ditetapkn oleh pihak yang berwenang, bukan hukum dalam arti lain misalnya putusan pengadilan bahkan yang hidup di masyarakat. (Moh. Mahfud MD, 2009: 70)

Akibatnya produk hukum perundang-undangan tidak lagi merefleksikn keadilan publik tetapi lebih pada kemenangan kepentingan partai politik yang menang. Nilai-nilai Pancasila tidak dikembangkan lagi, tidak sungguh-sungguh 
diterapkan. Tidak mengherankan kalau nilai-nilai spiritual Pancasila makin luntur dimana hal itu diperparah dengan tumbangnya Orde Baru yang diidentikkan dengan berakhirnya Pancasila (Rodiyah, Jurnal Konstitsi PKK Universitas Negeri Semarang Vol. 1 2008: 70).

Selain terlepasnya keadilan sebagai sukma hukum yang bersumber dari etika dan moral Pancasila masalah lain yang kita hadapi adalah hubungan antara hukum dan politik sebagai dua subsistem kemasyarakatan. Dalam hal penting tertentu hukum lebih banyak didominasi oleh politik sehingga sejalan dengan melemahnya dasar etik dan moral. Pembuatan dan penegakan hukum banyak diwarnai oleh kepentingan-kepentingan politik kelompok dominan yang sifatnya tekhnis, tidak substansial dan bersifat jangka pendek (Moh. Mahfud MD, 2012: 68).

Semenjak keesokan harinya setelah diproklamirkan kemerdekaan Indonesia oleh Ir. Soekarno, PPKI mengadakan sidang pertama dan menetapkan ideologi negara yang benar dan sah terdapat dalam Pembukaan UUD 1945 (sekarang Undang-Undang Dasar Negara Republik Indonesia 1945), yaitu Pancasila, (Gunawan Setiardja, 2006: 237) sebagai ideologi negara yang jika bertumpu pada filsafatnya secara singkat-bernas diungkapkapkan dalam kelima silanya, masa itu dikenal dengan masa Orde Lama.

Kemudian di masa Orde Baru dengan mengesampingkan segala penyimpangannya saat itu, selalu menyatakan melaksanakan Pancasila dan UUD 1945 dengan murni dan konsekuen terus didengungkan sehingga sangat mempengaruhi perikehidupan bangsa (muncul Ekonomi Pancasila bahkan sepakbola Pancasila) (Liek Wilardjo, 1990: 131). Sampai pada akhirnya Orde Baru runtuh dan kini kita memasuki Era Reformasi yang menurut pandangan penulis karena trauma terhadap masa Orde Baru di awal masa ini Pancasila jarang sekali dibicarakan sampai pada akhir-akhir ini membangkitkan kembali Pancasila dengan istilah empat pilar kebangsaan (Pancasila, UUD 45, NKRI, Bhineka Tunggal Ika). Tetapi bagaimanakah aktualisasi Pancasila sebagai landasan politik hukum di Indonesia? 


\section{B. Pengertian Politik Hukum}

Istilah politik hukum mengandung 2 kata yaitu politik dan hukum, dilihat dari perspektif etimologis, hubungan politik dengan hukum dalam istilah politik hukum dapat dijelaskan sebagai berikut : Istilah politik hukum dalam bahasa Belanda disebut "rechtspolitiek". Rechtspolitiek merupakan kata majemuk yang terdiri dari kata "recht” dan "politiek". Kata "recht” berarti hukum. Hukum adalah seperangkat aturan tingkah laku yang berlaku dalam masyarakat. Sedangkan kata “politiek” atau "belied” berarti politik (kebijakan). Politik atau kebijakan adalah rangkaian konsep dan asas yang menjadi garis besar dan dasar rencanan dalam pelaksanaan suatu pekerjaan, kepemimpinan, dan cara bertindak (Eddy Asnawi, Jurnal Dinamika Hukum Vol. 11 Edisi Khusus, Februari 2011: 16)

Selain itu politik hukum juga diartikan dengan legal policy atau garis (kebijakan) resmi tentang hukum yang akan diberlakukan baik dengan pembuatan hukum baru maupun dengan penggantian hukum lama, dalam rangka mencapai tujuan negara (Moh. Mahfud MD, 2012: 1). Satjipto Rahardjo mendefinisikan politik hukum sebagai aktifitas memilih cara yang hendak dipahami untuk mencapai suatu tujuan sosial dan hukum tertentu dalam suatu masyarakat (Satjipto Rahardjo, 2012: 352-353).

Abdul Hakim Garuda Nusantara mendefinisikan sistem politik hukum sebagai legal policy/kebijakan hukum yang hendak diterapkan atau dilaksanakan secara maksimal oleh suatu pemerintah negara terntentu untuk yang dapat meliputi pelaksanaan konstitusi dan ketentuan hukum yang ada, pembangunan hukum yang berintikan pembaruan atas hukum yang telah ada dan pembuatan hukum-hukum baru, penegasan pengisian lembaga penegak hukum sera pembinaan para anggota dan peningkatan kesadaran hukum masyarakat menurut persepsi elit pengambil kebijakan (Abdul Hakim Garuda Nusantar, September 1989: 5). Ada 3 model hubungan antara hukum dan politik. Pertama, hukum determinan atas politik. Kenyataan hubungan seperti ini didasarkan pada asumsi dan pandangan das sollen, apa yang seharusnya. Kedua, politik determinan atas hukum, dimana hal ini didasarkan pada 
pandangan menggunakan das sein, apa dan bagaimana kenyataannya. Ketiga, berdasar pada asumsi das sollen-sein hubungan hukum dan politik tak bisa dikatakan ada yang lebih dominan atau lebih unggul karena keduanya secara simetris saling mempengaruhi. Kalau misalnya politik diartikan sebagai kekuasaan, maka lahirlah pernyataa “politik dan hukum itu determinan”, karena politik tanpa hukum itu zalim sedangkan hukum tanpa politik itu lumpuh (Moh. Mahfud MD: 2013: vii-viii)

Bernard L. Tanya lebih menegaskan bahwa politik hukum sebagai agenda hukum untuk mewujudkan tujuan bersama yakni hukum harus hadir dalam mewujudkan tujuan hakiki hukum yaitu menjamin pengaturan adil, memberi kepastian hukum dan mendistribusi manfaat. Inilah yang membedakan politik hukum dengan politik yang lain seperti politik ekoknomi, politik kebudayaan dan lain sebagainya. Jadi dalam perspektif ini hukum tidak boleh dimanfaatkan untuk sembarang tujuan diluar tujuan ideal bersama masyarakat, bangsa dan negara (Bernard L. Tanya, 2011: 5).

\section{Hakekat Pancasila Bagi Indonesia}

Ketika kita akan menjadikan Pancasila sebagai landasan dalam politik hukum Nasional, sebelumnya kita harus mengetahui apa sebenarnya hakekat Pancasila bagi Indonesia, yaitu Falsafah Pancasila dengan kelima silanya memberikan pedoman hidup yang sempurna bagi segenap bangsa (Kesuma Jaya, 1989: 20).

Pancasila sebagai kontrak sosial, yaitu sebagai norma-norma yang disepakati bersama sebagai dasar kehidupan sosial dan dasar kenegaraan. Pancasila yang pada kaitannya dengan hukum selalu memiliki kecenderungan umum bahwa Pancasila ditempatkan sebagai bagian yang paling tinggi dari model piramida hukum Indonesia. Sebagaimana hal ini dijelaskan oleh Shidarta bahwa Pancasila menjadi bintang pemandu atau litstern, yang lapisanlapisan materinya berisi subtansi hukum dan tiang kerangkanya struktur hukum, serta lingkungan kehidupannya adalah budaya hukum (Anthon Susanto, 2010: hal. 294). 
Dardji Darmodihardjo menempatkan Pancasila sebagai sumber hukum dengan menggambarkan gagasan dari Hans Kelsen tentang Grundnorm atau norma dasar sebagai sumber dari segala sumber hukum Indonesia (Ibid). Sementara Max L. Stackhouse menilai pembaharuan hukum (pidana) di Indonesia terpenjara dalam rimba peraturan yang lahir dan terknstruksi dalam kosmologi ala Hegel, padahal kita memiliki Pancasila yang tidak hanya menyediakan kerangka ontologis dan normatif tetapi juga kerangka operaasional yang sangat kokoh bagi penataan kehidupan bangsa yang lebih baik bagi negeri ini (Bernard L.Tanya, 2011: 291). Notonagoro mengistilahkan Pancasila sebagai sebuah karya agung pendiri bangsa melalui The Founding Father yang merupakan hasil pemikiran elektis inkorporsi (Ibid). Liek Wilardjo juga secara bernas menyatakan bahwa Pancasila merupakan ciri khas bangsa Indonesia dan mempengaruhi kehidupan berbangsa dan bernegara rakyat Indonesia yang bertujuan menciptakan masyarakat adil dan makmur serta membentuk pranata sosial politis (Liek Wilardjo, 1990: 131).

Begitupula Arif Sidharta menjelaskan tentang cita hukum yang berakar pada Pancasila, yang secara formal dicantumkan dalam Pembukaan UndangUndang Dasar 1945. Cita hukum dapat dipahami sebagai konstruksi pikiran yang merupakan keharusan untuk mengarahkan hukum pada cita-cita yang diinginkan masyarakat, berfungsi sebagai tolok ukur yang berseifat regulatif dan konstruktif, tanpa cita hukum maka produk hukum yang dihasilkan akan kehilanngan maknanya (Esmi Warassih, 2005: 43). Cita hukum merupakan apa yang hendak dicapai oleh hukum. Cita hukum (rechtsidee) mengandung arti bahwa pada hakekatnya hukum sebagai aturan tingkah laku masyarakat yang berakar pada gagasan, rasa, karsa, cipta dan fikiran dari masyarakat itu sendiri. Jadi cita hukum itu adalah gagasan, karsa, cipta dan fikiran berkenaan dengan hukum atau persepsi tentang makna hukum (Anthon Susanto, 2010: 294).

Pancasila juga sebagai paradigma yaitu kumpulan tata nilai yang membentuk pola pikir sebagai titik tolak pandangan hidup, sumber nilai kerangka pikir, orientasi dasar, sumber asas serta arah dan tujuan dari suatu perkembangan, perubahan serta proses dalam suatu bidang tertentu termasuk 
dalam bidang pembangunan, reformasi maupun pendidikan (Kaelan, 2010: 227). Pancasila sebagai dasar negara mengandung nilai-nilai dasar dari kearifan lokal keIndonesiaan yang dijabarkan ke dalam kelima sila. Oleh karena itu, setiap sila Pancasila mengandung nilai sekaligus tujuan yang ingin dicapai bangsa ini kedepan. Kirdi Dipoyudo menyatakan bahwa pembangunan sebagai pengamalan Pancasila (Kirdi Dipoyudo, Jurnal Analisa CSIS, tahun XV, No. 8 Agustus 1996 )

\section{Aktualisasi Pancasila Sebagai Landasan Politik Hukum Indonesia}

Aktualisasi berarti pelaksanaan hingga benar-benar ada (terwujud), pewujudnyataan atau pengejawantahan (AKA Kamarulzaman, Dahlan Y, 2005: 23) yang dalam konteks aktualisasi Pancasila disini berarti bersamasama kita mewujudkan Pancasila sebagai landasan dalam pembuatan hukum (Peraturan Perundang-Undangang) baru maupun dengan penggantian hukum lama (politik hukum) agar dalam pelaksanaannya dapat mencapai keadilan yang menjadi tujuan hakiki hukum tersebut.

Indonesia lahir dengan Pancasila sebagai ideologi dan dasar negara yang sudah lahir terlebih dahulu pada sidang Dokuritsu Junbi Cosakai (Badan Penyelidik Usaha Persiapan Kemerdekaan) pada tanggal 1 Juni 1945. Pancasila adalah sebuah sistem filsafat yang merupakan rumusan ideal dalam bangun keindonesiaan yang dicita-citakan bangsa. Berbagai komponen bangsa seharusnya menggunakan dan mengembangkan implementasi sistem filsafat Pancasila dalam berbagai bidang (Soejadi, 1999: 183). Namun realitasnya, menurut Benny Susetyo, Pancasila yang sering diagung-agungkan sebagai falsafah bangsa, pedoman bertindak, identitas nasional, sumber hukum, dan cita-cita nasional, namun kenyataannya lebih sering dipandang sebagai simbol saja (Benny Susetyo, 2010: 214)

Bagi bangsa Indonesia, nilai-nilai Pancasila bahkan ditempatkan sebagai paradigma politik hukum. Pancasila memiliki nilai-nilai dasar yang bersifat universal dan tetap. Nilai-nilai itu tersusun secara hierarkis dan piramidal, mengandung kualiltas tertentu yang harus dicapai oleh bangsa Indonesia yang 
akan diwujudkan menjadi kenyataan konkret dalam kehidupan bermasyarakat (Kaelan, 2010: 70-71)

Dalam konteks politik hukum Pancasila dapat terlihat pada urgensi sebagai dasar hukum dan sumber hukum nasional terlihat dalam berbagai hasil seminar dan konvensi nasional, antara lain (Barda Nawawi Arief, Makalah Seminar Nasional FH Trunojono, Bangkalan, 2009) ;

1. Seminar Hukum Nasional ke-II menyatakan bahwa pelaksanaan UUD 1945 yang berlawanan dengan semangat dan jiwa Pancasila berarti manipulasi konstitusi dan penghianatan terhadap Pancasila

2. Seminar Hukum Nasional ke-IV menyatakan bahwa Pancasila merupakan nilai-nilai kejiwaan bangsa; dasar tertib hukum Indonesia; pedoman dan penunjuk arah; dan batu ujian mengenai kepatutan dan perundangundangan. Dinyatakan pula, perncerminan nilai-nilai Pancasila didalam perundang-undangan merupakan hakekat pembentukan sistem hukum nasional

3. Seminar Hukum Nasional ke-V tahun 1990 menyatakan bahwa pada akhir Repelita VI sudah harus tersusun pola pikir dan kerangka sistem hukum nasional berdasarkan Pancasila dan UUD 1945

4. Seminar Hukum Nasional ke-VI tahun 1994 menyatakan bahwa sistem hukum nasional yang juga merupakan sistem hukum Pancasila, harus merupakan penjabaran dari seluruh sila-sila Pancasila secara keseluruhan.

5. Rekomendasi Konvensi Hukum Nasional tahun 2008 dinyatakan bahwa perlu disusun Grand Design Sistem dan Politik Hukum Nasional dengan landasan UUD NRI 1945 sebagai landasan konstitusional dan Pancasila sebagai landasan filosofisnya.

Disamping hasil seminar dan konvensi tersebut, kedudukan penting Pancasila dalam sistem hukum nasional juga telah diatur dalam berbagai peraturan perundang-undangan, seperti dalam Pasal 2 Undang-undang Nomor 10 tahun 2004 tentang Pembentukan Peraturan Perundang-undangan menyatakan bahwa Pancasila merupakan sumber dari segala sumber hukum negara. Dalam penjelasan Pasal 2 disebutkan bahwa Penempatan Pancasila 
sebagai sumber dari segala sumber hukum negara adalah sesuai dengan Pembukaan Undang-Undang Dasar Negara Republik Indonesia Tahun 1945 yang menempatkan Pancasila sebagai dasar dan ideologi negara serta sekaligus dasar filosofis bangsa dan negara sehingga setiap Materi Muatan Peraturan Perundang-undangan tidak boleh bertentangan dengan nilai-nilai yang terkandung dalam Pancasila. Jadi jelaslah bahwa nilai-nilai Pancasila harus selalu melandasi setiap politik hukum bangsa Indonesia.

Selain itu agar dapat mengaktualisasikan Pancasila dalam politik hukum Nasional, maka sila-sila Pancasila harus dipandang sebagai suatu sistem nilai, sehingga pada hakikatnya Pancasila merupakan satu kesatuan. Adapun nilainilai yang terkandung dalam setiap sila adalah sebagai berikut (Kaelan, 2010: 79-84) :

1. Sila Ketuhanan Yang Maha Esa mengandung nilai bahwa segala hal yang berkaitan dengan pelaksanaan dan penyelenggaraan negara bahkan moral negara, moral penyelenggara negara, politik negara, pemerintahan negara, hukum dan peraturan perundang-undangan negara, kebebasan dan hak asasi warga negara harus dijiwai nilai-nilai Ketuhanan Yang Maha Esa.

2. Sila Kemanusiaan yang Adil dan Beradab adalah perwujudan nilai kemanusiaan sebagai makhluk yang berbudaya, bermoral dan beragama, serta adil dalam hubungan diri sendiri, sesama dan lingkungannya.

3. Sila Persatuan dan Kesatuan mengandung nilai bahwa negara Indonesia merupakan persekutuan diantara keberagaman yang dilukiskan dalam Bhinneka Tunggal Ika. Nilai-nilai nasionalisme harus tercermin dalam segala aspek penyelenggaraan negara.

4. Sila Kerakyatan yang Dipimpin Oleh Hikmat Kebijaksanaan dalam Permusyawaratan/Perwakilan mengandung nilai bahwa negara adalah dari, oleh dan untuk rakyat. Nilai demokrasi mutlak diterapkan dalam kehidupan bernegara, baik menyangkut aspek moralitas kenegaraan, aspek politik, maupun aspek hukum dan perundang-undangan.

5. Sila Keadilan Sosial Bagi Seluruh Rakyat Indonesia mengandung nilai yang merupakan tujuan negara sebagai tujuan bersama. Nilai keadilan 
harus terwujud dalam kehidupan bersama (keadilan sosial) yang bertujuan untuk kesejahteraan seluruh warga negara.

Barda Nawawi menyatakan bahwa sistem hukum nasional (SHN) pada hakikatnya adalah Sistem Hukum Pancasila. Apabila dijabarkan lebih lanjut, sistem hukum Pancasila adalah SHN yang berlandaskan/berorientasi pada tiga pilar/nilai keseimbangan Pancasila, yaitu :

1. berorientasi pada nilai-nilai "Ketuhanan” (bermoral religius);

2. berorientasi pada nilai-nilai “Kemanusiaan” (humanistik); dan

3. berorientasi pada nilai-nilai “Kemasyarakatan” (nasionalistik; demokratik; berkeadilan sosial).

Mochtar Kusumaatmadja yang menyatakan bahwa dalam negara hukum (Rule of law) untuk Republik Indonesia harus menganut asas dan konsep Pancasila yang terkandung dalam Pembukaan UUD 1945, yakni (Mochtar Kusumaatmadja, 1972: 11):

1. Asas Ketuhanan (mengamanatkan bahwa tidak boleh ada produk hukum nasional yang anti agama).

2. Asas Kemanusiaan (mengamanatkan bahwa hukum nasional harus menjamin, melindungi hak asasi manusia).

3. Asas Kesatuan dan Persatuan (mengamanatkan bahwa hukum Indonesia harus merupakan hukum nasional yang berlaku bagi seluruh bangsa Indonesia, berfungsi sebagai pemersatu bangsa).

4. Asas Demokrasi (mengamanatkan bahwa kekuasaan harus tunduk pada hukum yang adil demokratis).

5. Asas Keadilan Sosial (mengamanatkan bahwa semua warga negara mempunyai hak yang sama bahwa semua orang sama dihadapan hukum).

Berdasarkan penjelasan tersebut di atas Pancasila menjadi landasan atas politik hukum Indonesia. Hukum harus berdasarkan pada Pancasila, produk hukum boleh dirubah sesuai dengan perkembangan zaman dan pergaulan masyarakat, tentunya Pancasila harus menjadi kerangka berfikir. Pancasila dapat memandu politik hukum nasional dalam berbagai bidang, yaitu (Moh. Mahfud MD, 2006: 17-18) 
1. Sila Ketuhanan Yang Maha Esa menjadi landasan politik hukum yang berbasis moral agama

2. Sila Kemanusiaan yang Adil dan Beradab Esa menjadi landasan politik hukum yang menghargai dan melindungi hak-hak asasi manusia yang nondiskriminatif

3. Sila Persatuan Indonesia menjadi landasan politik hukum yang mempersatukan seluruh unsur bangsa dengan berbagai ikatan primordialnya masing-masing

4. Sila Kerakyatan yang Dipimpin Oleh Hikmat Kebijaksanaan dalam Permusyawaratan/Perwakilan menjadi landasan politik hukum yang meletakkan kekuasaan di bawah kekuasaan rakyat (demokratis)

5. Sila Keadilan Sosial Bagi Seluruh Rakyat Indonesia menjadi landasan politik hukum dalam hidup bermasyarakat yang berkeadilan sosial sehinga mereka yang lemah secara sosial dan ekonomis tidak ditindas oleh mereka yang kuat secara sewenang-wenang

Menurut Mahfud MD, ada dua alasan pokok yang menyebabkan Pancasila tidak dapat diganggu gugat, yaitu yang pertama, Pancasila sangat cocok dijadikan platform kehidupan bersama bagi bangsa Indonesia yang sangat majemuk agar tetap terikat erat sebagai bangsa yang bersatu, dan yang kedua, Pancasila termuat dalam pembukaan UUDNRI 1945 yang di dalamnya ada pernyataan kemerdekaan oleh bangsa Indonesia sehingga jika pancasila diubah maka berarti Pembukaan UUDNRI pun diubah. Pancasila telah mampu memposisikan dirinya sebagai tempat untuk kembali jika bangsa Indonesia terancam perpecahan.

\section{E. Simpulan}

Pancasila merupakan landasan utama dalam pembuatan hukum (Peraturan Perundang-Undangang) baru maupun dengan penggantian hukum lama (politik hukum), sehingga nilai-nilai Ketuhanan, Kemanusiaan dan Kemasyarakatan (nasionalistik; demokratik; berkeadilan sosial) harus teraktualisasi kedalam substansi hukum, struktur hukum maupun kultur hukum yang akan dibangun, diharapkan dapat menguatkan integrasi bangsa, demokratisasi hukum, 
tercapainya kesejahteraan dan keadilan sosial dengan menempatkan Pancasila, mulai dari nilai, tujuan sampai dengan aktualisasi kepada berbagai bidang hukum yang ada, baik hukum pidana, perdata, tata usaha negara dan lain-lain, serta internalisasi pada struktur hukum dan budaya hukum Pancasila.

\section{Daftar Pustaka}

Abdul Hakim Garuda Nusantara. 1989. Politik Hukum Nasional. Makalah Pada Karya Latih Bantuan Hukum diselenggarakan Oleh Yayasan LBH Indonesia dan LBH Surabaya.

AKA Kamarulzaman, Dahlan Y. 2005. Kamus Ilmiah Serapan. Yogyakarta : Absolut.

Anthon Susanto. 2010. Ilmu Hukum Non Sistematik "Fondasi Filsafat Pengembangan Ilmu Hukum Indonesia”. Yogyakarta : Genta Publishing.

Bambang Sugono. 2006. Metode Penelitian Hukum. Jakarta : Raja Grafindo Persada.

Barda Nawawi Arief. 2009. Implementasi Ide-Ide Dasar Pancasila dalam Pembaharuan Hukum Pidana Indonesia. Makalah Seminar Nasional FH Trunojono. Bangkalan.

Benny Susetyo. Ketidakadilan Kemerdekaan dalam Rindu Pancasila. Jakarta : Kompas Media Nusantara.

Bernard L. Tanya. 2011. Politik Hukum Agenda Kepentingan Bersama. Yogyakarta : Genta Publising.

Publising.

Esmi Warassih. 2005. Pranata Hukum Sebuah Telaah Sosiologis. Semarang : Suryandaru Utama.

Gunawan Setiardja. 2010. Berpikir Secara Filsafati Sebagai Sarana Memahami Pancasila Baik Sebagai Ideologi Maupun Sebagai Dasar Negara, dalam Menggagas Hukum Progrsesif Indonesia. Pustaka Pelajar Yogyakarta dan Program Doktor Ilmu Hukum Universitas Diponegoro. Semarang.

Kaelan. 2010. Pendidikan Pancasila. Yogyakarta : Paradigma.

Kartono. Politik Hukum Judicial Review di Indonesia. Jurnal Dinamika Hukum Vol. 11 Edisi Khusus. Februari 2011.

Kesuma Jaya. 1989. Pancasila ditinjau secara Filsafat-1. Bandung : Tarsito.

Kirdi Dipoyudo. Pembangunan Sebagai Pengamalan Pancasila. Jurnal Analisa CSIS. tahun XV. No. 8 Agustus 1996.

Lev, Daniel S. 2013. Hukum Dan Politik Di Indonesia Kesinambungan dan Perubahan. Jakarta : LP3ES.

Liek Wilardjo. 1990. Realita dan Desiderata. Yogyakarta : Duta Wacana University Press.

Mardalis. 1990. Metodologi Penelitian Suatu Pendekatan Proposal. Jakarta ; Bukit Aksara. 
Mochtar Kusumaatmadja. 1972. Pembinaan Hukum Dalam Rangka Pembangunan Nasional. Bandung : Bina Citra.

Moh. Mahfud MD. 2006. Membangun Politik Hukum, Menegakkan Konstitusi, Pustaka Jakarta : LP3ES.

: Rajawali Pers. 2009. Konstitusi Dan Hukum Dalam Kotroversi Isu, Jakarta 2012. Konstitusi Dan Hukum Dalam Kontroversi Baru. Jakarta : Rajawali Pers.

\section{Persada.}

Mumpuni Martojo. 2007. Modul Kuliah Politik Hukum. Magister Ilmu Hukum Universitas Diponegoro.

Rodiyah. Ironis Badan Permusyawaratan Desa (BPD) Antara Harapan Dan Realitas Dalam Sistem Hukum Politik Indonesia. Jurnal Konstitsi PKK Universitas Negeri Semarang Vol. 1, November 2008.

Satjipto Rahardjo. 2012. Ilmu Hukum. Bandung : Citra Aditya Bakti.

Soejadi. Pancasila sebagai Sumber Tertib Hukum Indonesia, Lukman Offset, Yogyakarta. 1999 